the dark web, where law enforcement faces much greater challenges.

We thank B.M. Attewell, J.A. Cripps, J. Duah and D. McRobert for assisting in monitoring wildlife trade on the dark web as part of their final year undergraduate project, and Michael t'Sas Rolfe for useful discussions on illegal wildlife trade and the term bycatch.

DAVID L ROBERTS Durrell Institute of Conservation and Ecology, School of Anthropology and Conservation, University of Kent, Canterbury, Kent, UK, and Interdisciplinary Centre for Cyber Security Research, University of Kent, Canterbury, Kent, UK

E-mail d.l.roberts@kent.ac.uk

Julio HeRnANDEZ-CASTRO Interdisciplinary Centre for Cyber Security Research, University of Kent, Canterbury, Kent, UK, and School of Computing, University of Kent, Canterbury, Kent, UK

\section{Instagram-fuelled illegal slow loris trade uncovered in Marmaris, Turkey}

Exploitation of wildlife on social media is becoming a matter of international concern. Even the most commonly used social media platforms, including Facebook, Twitter, YouTube and Instagram, remain unresponsive to the exploitation of protected species illegally kept as pets and featured in hundreds of viral images and videos. Researchers have shown that people who see threatened species in a human context perceive them as less threatened and as suitable pets. Asia's slow lorises (Nycticebus spp.) are one taxon heavily exploited on social media and featured as both pets and photograph props for tourists. Until now the latter threat has been largely restricted to Thailand, as made infamous by a selfie of pop singer Rihanna, who posted on Instagram an image of herself in Thailand in 2013 with two illegally traded pygmy slow lorises (N. pygmaeus). Here we present the first evidence of the expansion of the tourist photograph prop trade of slow lorises into Europe. Through exploration of Instagram and direct observations in Turkey, we highlight the popular tourist destination Marmaris, Turkey, as a prime location for slow loris photograph props.

We located photographs on Instagram of animal props in Marmaris, including 135 of slow lorises ( $37 \%$ showed N. pygmaeus and $63 \%$ showed the Bengal slow loris N. bengalensis) posted between August 2012 and January 2017. Other wild animals appearing in posts included sugar gliders, macaws, turtles, vervet monkeys and rabbits. In the posts with slow lorises, uploaders hash tagged them as slow loris, lemur, monkey or bushbaby. Although $83 \%$ of the photographs were taken at night, the remainder showed the slow loris paraded in bright daylight; $62 \%$ of photographs featured the slow loris dressed in clothing. Females (84\%) were much more likely to post a photograph of themselves with a slow loris than males (16\%).

To obtain presence data and assess the welfare of slow loris photograph props first hand, we conducted two investigations in Marmaris in April (7 days) and June (4 days) 2016. When we located wildlife photograph props we recorded the species and descriptive information on health and welfare. We collected evidence while posing as normal tourists, without encouraging or promoting the illegal wildlife trade.

We located two Bengal slow lorises (one juvenile and one adult), and one adult pygmy slow loris in a beach bar in Marmaris. The vendor referred to the slow lorises as lemurs, whereas the bar owner referred to them as sloths. For 10 lira (c. USD 2.75) tourists could have their photograph taken by the vendor and printed out to take away, or they could play with the slow loris, and take photographs with their own devices. Although we did not observe slow lorises during daylight, hours, the bar contained bright lights, and flash photography was frequently used, causing both stress and potential damage to the sensitive eyes of the slow lorises.

When not being used to entice tourists or being held by tourists, the slow lorises were stored behind a small DJ booth. They were fed unsuitable foods, including cherries, grapes and even a wedge of orange taken from a cocktail. Feeding by the vendor or the tourists occurred only when tourists paid to play with the animals. Contrary to evidence we gathered from Instagram, we did not observe slow lorises dressed in clothing. Both of the Bengal slow lorises had had their teeth clipped; this is normally done to prevent them from inflicting their venomous bite.

Bengal and pygmy slow lorises are categorized as Vulnerable on the IUCN Red List and included on Appendix 1 of CITES, and capturing them is illegal in all range countries where they occur. According to the CITES Trade Database, no non-human primate has ever been legally imported into Turkey, confirming the illegal import of these individuals. Efforts are needed to continue to raise awareness of the plight of slow lorises. Without a change in attitude from the public, the use of slow lorises as photograph props is likely to continue and to spread.

HONOR KITSON and K.A.I. NEKARIS Nocturnal Primate Research Group, Oxford Brookes University, Oxford, UK E-mailanekaris@brookes.ac.uk

\section{A new seed bank for Hispaniola to support the conservation and sustainable use of the Caribbean native flora}

In the Caribbean Islands global biodiversity hotspot, a highly diverse flora (13,00o plant species, of which 6,550 are endemics) struggles to coexist with a high human population 
density (164 people per $\mathrm{km}^{2}$; Mittermeier et al., 2011, in Zachos \& Habel, Biodiversity Hotspots, pp. 3-22), and overexploitation of natural resources is putting plant diversity and related ecosystem services under threat. A significant step for the effective conservation of the native flora of the Caribbean Islands was taken on 7 February 2017, when the new seed bank of the Jardín Botánico Nacional 'Dr. Rafael Ma. Moscoso' of Santo Domingo in the Dominican Republic was officially launched. This seed bank is the result of a long-term collaboration between the Jardín Botánico Nacional and the Royal Botanic Gardens, Kew, and is regulated under an access and benefit-sharing agreement. This started in 2007 within the Millennium Seed Bank Partnership and is continuing through The Global Tree Seed Bank Project, Saving the Threatened Forest of Hispaniola, funded by the Garfield Weston Foundation. This collaboration has already led to the duplication and germination testing of 328 seed lots (194 species) at Kew's Millennium Seed Bank in the UK. In addition, the technical and scientific support of Kew staff during the last 10 years contributed to the design of the Jardín Botánico Nacional seed bank in line with international standards for long-term conservation in gene banks.

The opening of this seed bank not only strengthens the capacity of the Jardín Botánico Nacional to conserve the seeds of the flora of Hispaniola in-country, contributing towards Target 8 of the Global Strategy for Plant Conservation (At least $75 \%$ of threatened plant species in ex situ collections, preferably in the country of origin, and at least $20 \%$ available for recovery and restoration programmes), but will also facilitate research on seed biology of tropical tree species, for which information on seed storage behaviour is currently lacking. In particular, the project is screening the seed storage behaviour of endemic, threatened and useful tree species of the island. The results of this study will facilitate the appropriate seed management of native trees in reforestation programmes on the island.

The Jardín Botánico Nacional seed bank will be a platform for the conservation of the native flora of the Dominican Republic, and for supporting reforestation programmes both there and in neighbouring Haiti. With an emphasis on useful trees, the seed conservation programme will also contribute to the livelihoods of the island and in particular to UN Sustainable Development Goal 2 (Zero Hunger) by maintaining the genetic diversity of seeds, and goal 15 (Life on Land). In addition, the sustainable use of the stored seeds of native species in reforestation programmes will contribute to goal 1 (No Poverty), Goal 3 (Good Health and Well-being) and Goal 13 (Climate Action).

These new facilities and scientific collaboration between the Jardín Botánico Nacional and the Royal Botanic Gardens, Kew, working together with existing governmental and research institutions in the Caribbean Islands, will play a pivotal role in supporting reforestation and livelihoods in the region.
Efisio Mattana, Keith R. Manger, Michael J. Way and Tiziana Ulian Royal Botanic Gardens, Kew, Ardingly, West Sussex, UK. E-mail e.mattana@kew.org

Ricardo Garcia, Wilkin Encarnacion, Teodoro Clase, Brigido Peguero and Francisco Jimenez Jardín Botánico Nacional 'Dr. Rafael Ma. Moscoso', Santo Domingo, Dominican Republic

\section{First photographs of chimpanzees in the Omo Forest Reserve, Nigeria}

An opportunistic camera-trap survey has captured the first evidence in over 10 years that chimpanzees Pan troglodytes survive in the Omo Forest Reserve, Ogun State, Nigeria. Two photographs taken at separate locations on 2 September 2016 are the first photographic evidence of this species in Omo and the first confirmed records since nests and vocalizations were reported in June 2006 (Greengrass, 2006, A Survey of Chimpanzees in South-West Nigeria, nigeria.wcs.org/wildlife/nigeria-cameroon-chimp. aspx). Fieldwork by the Omo-Shasha-Oluwa Forest Initiative had already established that local communities knew of the continued existence of chimpanzees, and a sighting of three individuals had been reported in July 2015. Chimpanzees in south-west Nigeria are included in the Regional Action Plan for the Conservation of the NigeriaCameroon Chimpanzee P. troglodytes ellioti, although their taxonomic status has yet to be determined genetically. Other globally threatened vertebrates recently recorded in Omo include African elephants Loxodonta africana (assumed to be the forest taxon cyclotis), red-capped mangabey Cercocebus torquatus, Nigerian white-throated guenon Cercopithecus erythrogaster pococki, white-bellied pangolin Phataginus tricuspis, grey parrot Psittacus erithacus, yellow-casqued hornbill Ceratogymna elata and African dwarf crocodile Osteolaemus tetraspis.

The Omo Forest Reserve, together with the contiguous Shasha and Oluwa Forest Reserves, in Osun and Ondo States, respectively, constitutes one of the largest remaining forested areas is south-west Nigeria, a region largely neglected by international conservation efforts despite the presence of threatened species. Located in the transition zone between the Upper and Gulf of Guinea forest biomes, this area was formerly part of a large swath of forest linking the dry forest of the Dahomey Gap (Togo and Benin) to the Niger Delta and stretching up to $400 \mathrm{~km}$ inland from the coast.

The remaining patches of natural forest are largely within state forest reserves established by the British colonial government in the early 2oth century for timber production and watershed protection. In some cases, communities living within the boundaries of forest reserves were permitted to remain, within legal enclaves. There was also high 